\title{
Performing Darna: The Role of Entertainment Press in Spectacularizing Darna Actresses ${ }^{1}$ Cherish Aileen A. Brillon
}

\begin{abstract}
This paper looks at the actresses who portrayed Darna and how they are presented as spectacles in the entertainment articles that promote the film and television adaptations. This frame of inquiry comes from the notion that the visual aesthetics of Darna in komiks is largely informed by the superhero genre's dependence on spectacle as shown in the superhero's feats of greatness and in her actions and movements which are all larger than life and extraordinary. If this is the case for Darna in print, then how about the actresses tasked with performing her in the movies and television series? How are their bodies being turned into a spectacle in promotional materials in order to conform to the needs of the capital (entertainment industry)?

In using the spectacle of the body as framework, the paper also draws on the star system and the role of producers of text in the creation of Darna as we know her today. The aim is to reveal how female bodies were made part of the construction of Darna's image outside of its fictional universe which results in a discourse that highlights the body of the celebrities rather than Darna's continuing relevance as a Filipino icon. This sets aside her representational power to embody the struggle and demand of Filipinos for justice and a better life as audience's attention is diverted towards how these actresses prepared their bodies to perform Darna.
\end{abstract}

Keywords: Body, celebrity culture, Darna, superheroes, spectacle 


\section{Plaridel Open Access Policy Statement}

As a service to authors, contributors, and the community, Plaridel: A Philippine Journal of Communication, Media, and Society provides open access to all its content. To ensure that all articles are accessible to readers and researchers, these are available for viewing and download (except Early View) from the Plaridel journal website, provided that the journal is properly cited as the original source and that the downloaded content is not modified or used for commercial purposes. Plaridel, published by the University of the Philippines College of Mass Communication is licensed under Creative Commons Attribution-NonCommercial-NoDerivatives 4.0 International License (https://creativecommons.org/ licenses/by-nc-nd/4.0/legalcode).

\section{How to cite this article in APA}

Brillon, C. A. A. (2021). Performing Darna: The role of entertainment press in spectacularizing Darna actresses. Plaridel, 18(1), 31-54. https://doi.org/10.52518/2020-09brllon 
Superheroes are big business in today's globalized world. What was initially thought of as a children's world, a kind of low-brow pleasure, has become one of the most profitable products to have come out of the entertainment industry in recent years, but they are so often dismissed as commodified products whose sole reason for existing is to rake in profits (Pyle, 1994; Salkowitz, 2018). As someone who grew up watching them, these fictional characters are more than just fantasies, but also repositories of contested images that have to do with representations and ideologies on gender and bodies.

Mars Ravelo and Nestor Redondo created Darna, a Filipino female superhero who continues to reign supreme over other local superheroes. Her story underwent many changes through the years, but Filipinos are still familiar with how a young girl named Narda found a mysterious stone with the name Darna engraved on it. In times of trouble, Narda would invoke Darna's name and she would transform into a tall, powerful, warrior woman that is not of this world.

Since her first appearance in Pilipino Komiks in the 1950's, Darna became a popular source material for movie and television adaptations, with thirteen movies, excluding her cameos in other films, and three liveaction television series in 1977, 2005, and 2009 (Lent, 2009).

This paper looks at the actresses who portrayed Darna and how they are presented as spectacles in the entertainment articles that promote the film and television adaptations. This frame of inquiry comes from the notion that the visual aesthetics of Darna in komiks is largely informed by the superhero genre's dependence on spectacle as shown in the superhero's feats of greatness and in her actions and movements which are all larger than life and extraordinary. If this is the case for Darna in komiks, then how about the actresses tasked with performing her in the movies and television series? How are their bodies transformed into a spectacle in promotional materials in order to conform to the needs of the capital (entertainment industry)?

This is in response to Soledad Reyes' (2009) challenge that studies about contemporary popular culture will only continue to be relevant if the focus of analysis shifts from what the text says to the conditions of its production, including discussing the role of the producers of the text, the star system, and the audiences (p. 9). In using the spectacle of the body as framework, the paper also draws on the star system and the role of producers of text in the creation of Darna as we know her today. The aim is to reveal how female bodies were made part of the construction of Darna's image outside of its fictional universe which results in a discourse that highlights the body of the celebrities rather than Darna's continuing relevance as a Filipino icon. 
This strategy sets aside her representational power that can have subversive possibilities. Further, this paper also hopes to contribute to the growing literature on body politics in the superhero genre.

Spectacle is defined in this study as how Darna actresses are represented in entertainment articles using rituals that are meant to further propagate the notion of what performing or playing Darna entails and presenting this as a celebration of an aestheticized (idealized) celebrity female body that has economic implications for the entertainment industry. As Erin Meyers (2014) argues, "female stars function as a site of spectacle and tobe-looked-at-ness that foregrounds their bodies as the site of meaningmaking in textual sources" (p. 57). Public relations, exemplified in this paper as promotional and publicity materials written by the entertainment press in selected komiks-magazines, is an essential part in the spectacularization process of female bodies. According to David Kellner (2003), public relations is an important cog in the culture industry machine because they are in charge of hyping celebrities, elevating them to a certain status, constantly managing their public and even private personas to ensure that they retain mass support especially in this age where image has become a marketable commodity (p. 5). In fact, it is public relations that can "make or break a celebrity" (p. 9).

This qualitative analysis covers available print and audio-visual promotional materials for all the actresses who played Darna in thirteen movies (excluding cameos) and in three television series. The focus is not on the content of the films and TV series per se, but on entertainment writeups found in selected komiks-magazines that were culled from archival research and recorded and uploaded Darna primers produced by GMA-7. ${ }^{2}$ Darna's publicity materials were analyzed according to a.) descriptions of their physique, b.) descriptions of their diet and exercise, and c.) stories of their preparation for Darna's two-piece red costume. These are then thematically presented according to the definition of ritualization and aestheticization provided below.

Great care is done to ensure the complete citation of archived materials such as the name of the entertainment writer, title and year of publication, and page numbers. However, there were instances when the material condition (brittleness of the paper, loose pages, among others) of some of these archived materials did not provide these details.

Previous personal interviews with Redgie Acuña-Magno, production unit manager of the 2005 Darna TV series, Ms. Angel Locsin, and secondary materials lifted from Celeste Landicho and Kate Mirandilla's (1999) interview with William Leary (deceased), one of the producers for the two Darna movies by Viva Films, were used to supplement the paper's assertion 
on the entertainment industry's role in focusing on the bodies of celebrities as a requirement to portraying Darna.

This paper starts with an overview of how female bodies are represented in various genres, particularly the superhero, before moving on to describe how spectacle works as the paper's framework. This is followed by an introduction of all seven actresses who portrayed Darna, including descriptions of their costumes. The final section discusses how the entertainment industry created a spectacle out of these bodies through rituals and the celebration of an aestheticized superhero body.

\section{Representations of bodies in genres}

In a "star" system, the individual or the celebrity is an important fulcrum in the process of producing, marketing and distributing cultural products and in the management of audience's expectations of these products (McDonald, 2000). A celebrity is a commodity traded by promotions, publicity, and media industries that produce these representations and their effects (Turner, 2004, p. 9). Movies and television programs are produced to cater to the stars/celebrities because they ensure support for these products so much so that they continue to command higher fees in return. In this definition, the role of promotions and publicity are immediately obvious as they are considered an integral part in an entertainment system that is designed to constantly capture and hold our attention.

Meyers (2014) mentioned that scholarly approaches to stardom have "historically been rooted in the body as it is a physical form that anchors the meaning-making process through which audiences create and negotiate meaning" (p. 56). In gender studies, the body is the site of practices and policies through which powers of society regulate the human body, including the struggle over the degree of individual and social control (Jacobus, Keller \& Shuttleworth, 1990). In short, the construction and manufacture of stars are materially done and exemplified in their bodies. In portraying a certain role (action hero, heartthrob, or a sexy star) it is in the body that the traits and images associated with these roles are codified because this is what is seen and projected on the screen and delivered to millions of viewers. For this paper, it is through the body of female celebrities that notions of control and discipline, associated with spectacle and capitalism are mapped and worked out.

There have been several studies that look at how women's bodies have been traditionally represented in various genres. As for example, Yvonne Tasker (1993) and Soledad Reyes (2001) both pointed out that in the action genre, a woman's body is always violated (kidnapped, raped, killed) and treated as a plot device to serve the male hero's redemption arc. In the 
local melodrama, Arminda Santiago (2001) specifically mentioned that a woman's body becomes the site of sacrifice and where issues on family and the private space are worked out. In the bomba (sex) genre, Marra Lanot (2001) observes that a woman's body continues to be a site of punishment because sex is still associated with and limited by cultural and religious notions.

In the superhero genre, the body constitutes some of the areas of analysis because it is considered as the symbol of power which is reified as a hyper-physical body (Boney, 2013). This is especially true when looking at superheroines because it is their bodies that are typically sexualized. According to Mel Gibson, David Huxley, and Joan Ormrod (2015), female bodies are constructed to be looked at interdiegetically by males within the story and by the male audiences. Anita McDaniel (2014) and Mike Madrid (2009) pointed out that it is the superhero costume that highlights the identity elements valued by the reader. If a costume exposes a lot of skin, it draws the reader's attention towards less-valued human elements such as race, gender, and physical attractiveness, while a body covered in costume diverts the reader's attention towards more valued elements such as strength and the ability to perform heroic acts. Following this argument, a quick glance at the gallery of Western superheroes reveal that it is typically the woman who wears body-revealing costumes while the men are noticeably fully-clothed. For Richard Gray (2011), men's costume is functional and highlights their physical strength while women's costumes are entirely for aesthetic purposes, highlighting their perfection in the form of sexual appeal.

It is largely through the element of costume that the superhero performs as it not only puts the body on display for everyone to see, but also emphasizes its action, activity, and power. There is now an element of physical performance that comes into play when actors/actresses take on the role of the superhero. In the case of Darna, there is a demand to achieve a perfect body especially as the red two-piece costume exposes a lot of skin. In fact, Darna's costume is actually more revealing compared to Wonder Woman's original costume (an eagle bustier that covered her body and almost knee-length culottes).

\section{Body and spectacle}

As a theoretical construct, spectacle is largely associated with Guy Debord (1995) who defined it as the power of images to mediate social relations (p. 10). Debord's spectacle is an overarching concept as it also talks about the sense of alienation and degradation that comes from living in a consumer society, with media implicated as one of the instruments of capitalism. 
His analysis also sees spectacle as an instrument of the status quo because it conceals the exploitative relations among people in different classes of society.

Building from these concepts, Kellner (2003) considers spectacle as an essential part of media culture because of its potential to construct political and social realities. He focuses on media spectacle which he defined as representing "contemporary society's basic values, serving to initiate individuals into its way of life, and dramatizing controversies and struggles, as well as its modes of conflict resolution" (p. 2). Thus, the notion of media spectacle possesses ritualistic, mediated, commercialized and aestheticized attributes.

Spectacle is also a word that best describes the superhero genre because it talks about people attaining extraordinary and spectacular powers to vanquish their opponents. Patrick Campos (2009) traces the genesis of local superhero movies under the broader field of fantasy and action where he emphasized it as a "visual spectacle of the fantastic in terms of cinematic spaces, costumes, and magic" (p. 7) and whose epic quality comes in the form of the "excitement of combat, the exhilaration of manipulated time (acceleration and protraction), and the visceral evocation of movement in a spectacular scale" (p. 6).

What is the connection of spectacle to the celebrity body?

For the entertainment industry to profit on the body of a star, it has to be seen in full display and on a larger scale. Kellner (2003) sees media spectacle as a culture of celebrity because they provide the "dominant role models and icons of fashion, look, and personality" (p. 5). Celebrities are brands and as Richard Dyer (1987) notes, they are not just passive "products" of a capitalist machinery, but are themselves complicit in transforming themselves as commodities. For Dyer, what is more dangerous is that these stars or celebrities are just "media hype, foisted to us by media's constant need to manipulate our attention" (p. 15). As mentioned above, it is the public relations industry which hypes and transforms these celebrities into spectacles.

For this paper, I loosely borrowed Kellner's (2003) idea of spectacle, especially the elements of ritual and aesthetics. Ritualistic practices highlight the ideals associated with a personality or an event, while aesthetics talk about its narrative aspects. These two strategies are subtly integrated in the entertainment write ups about Darna. The selected articles make use of rituals by pointing to the legacy and honor that comes with performing Darna. On the other hand, aestheticization comes in the form of how these write ups frame stories of the actress' preparations for the role in order to transform their bodies fit for a superhero. In the end, spectacle only serves to 
celebrate the triumph of the entertainment industry to further commodify the celebrity while shifting the conversation away from Darna's subversive possibilities.

\section{Darna actresses}

Darna remains an interesting figure for academic analysis not only because of her enduring popularity, but also because she remains a complex figure open to interpretations. Previous studies on Darna include exploring the tension inherent in being a powerful woman, but still imagined within a patriarchal framework (Escobar, 2010; Lucero, 2001) and as an example of how popular culture figures are commodified (Brillon, 2007a, 2007b; Gerona, Goze, Lumidao, \& Yu, 2009). However, what is less explored in these earlier studies is the role of spectacle and how it is integrated in all aspects of the production and further propagation of superhero texts.

Spectacle is immediately integrated in choosing the actor/actress who will portray the superhero. In Darna, this process is further amplified in entertainment press releases that appeared in newspapers and komiksmagazine, in the screening of Darna primers prior to the premiere of the television series (2005 and 2009 TV series), and in the interviews with previous actresses. As for example, the audition for the 2005 Darna series was highly publicized with a steady stream of news about GMA talents vying for the role ("Angel Locsin shouts 'Darna," 2005). Nowadays, the amplification has even taken on a more crowd-sourced characteristic via social media. Even before the selection of Jane de Leon as the new Darna in an upcoming Star Cinema adaptation, fans of various actresses created fan campaigns, fan art, and fan vids. Entertainment publications and websites such as Preview and Starmometer even opened a voting poll featuring the most popular contemporary female celebrities and asked the fans to vote for them.

Much fanfare is accorded to the celebrity because he/she is the one in charge of breathing life to an already larger than life character. Sometimes a celebrity can make the superhero more popular than he/she already is, as in the case of Robert Downey Jr's portrayal of Iron Man, but at other times the superhero becomes the key to a celebrity's stardom like what Wonder Woman did to Gal Gadot. This section introduces the actresses who played Darna in featured roles in movie and television adaptations, describes their status in the entertainment industry when they were selected to play Darna, and descriptions of their costumes. This is to give background on how Darna's costume has remained the same throughout the years, hence the same focus and demand on the bodies of female celebrities.

Rosa del Rosario portrayed the first ever Darna onscreen in Darna (Poe, 
1951) and Darna at ang Babaeng Lawin (Darna and the Hawk Woman) (Poe \& Tolosa, 1952). She was personally handpicked by Poe with whom she previously worked with in the film Zamboanga (1937), with the blessing of Darna's creator, Mars Ravelo. In both films, her costume followed the komiks version created by Nestor Redondo: red two-piece with gold stars and a white loincloth, red helmet with a gold winged medallion and a ruby in the middle, gold bracelets and belt, and knee-high red boots. It is also assumed that Rosa del Rosario's facial features, height, and physique comes closest to what Darna looks like in the komiks since fidelity to the stories is the norm during those times (see: Arriola, 2013).

The sixties produced three Darnas: Liza Moreno, Eva Montes, and Gina Pareño.

Liza Moreno was a supporting actress before being cast in Darna at ang Impakta (Darna and the Monster) (Santiago, 1963) and Isputnik vs. Darna (Laxa \& Catindig, 1963). Her costume is almost similar to del Rosario's. On the other hand, Eva Montes (see fig. 1), who was a leading lady to action stars, was the first Darna to sport short hair under the headdress in Darna at ang Babaeng Tuod (Darna and the Wooden Monster) (Santiago, 1965). Her costume was changed to a gold two-piece with red stars, gold headdress and boots with a red loincloth. Gina Pareño was one of the most sought-after stars of Vera-Perez Pictures when she was chosen to play the superheroine in Si Darna at ang Planetman (Perez \& Navarro, 1969). The movie reinvented the costume again by making it a light blue two-piece with a red star, red headdress, gold bracelets and belt, and a red loincloth.

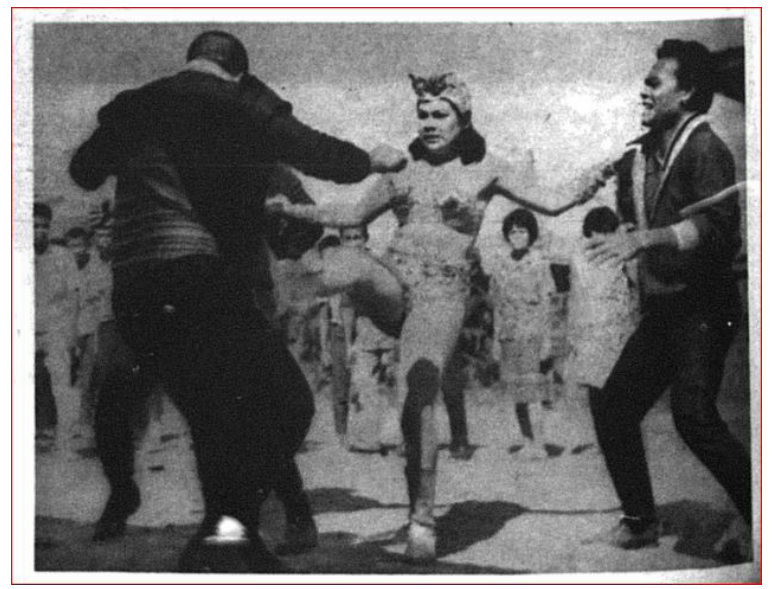

Figure 1. Eva Montes as Darna (Liwayway Magazine, 1965, National Library Microfilm)

When we talk about Darna in the seventies and eighties, it was synonymous to one name: Vilma Santos, who was a popular young star then and a part of the Vi-Bot loveteam. She starred in four films namely Lipad, Darna, Lipad (Fly, Darna, Fly), Darna and the Giants, Darna vs. 
The Planetwomen, and Darna at Ding (Darna and Ding). Darna's costume underwent a lot of changes in these different films. In Lipad (Quijano, Borlaza, Perez, Gosiengfiao, 1973), Darna went back to the original red two-piece with gold stars and red headdress, but partnered it with gold boots and bracelets, and red loincloth (see fig. 2). In Giants (Laxa, Borlaza \& Diaz, 1973), it became a gold two-piece with red stars, red loincloth, gold headdress, and boots. For Planet Women (Laxa \& Garces, 1975), it transformed

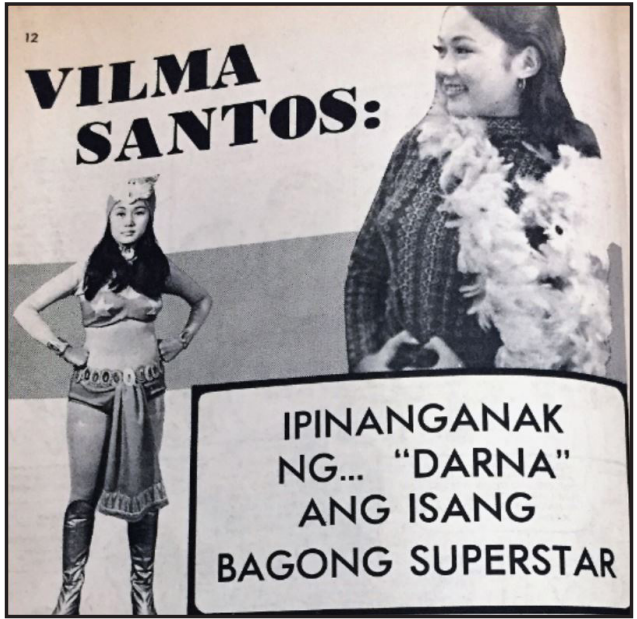

Figure 2. Vilma Santos as Darna (Darna Komiks, 1973, UP Diliman Library). again to a dark blue two-piece with red stars, a gold headdress and belt, red loincloth, boots, bracelets, and a choker. For Darna at Ding (Muhlach,

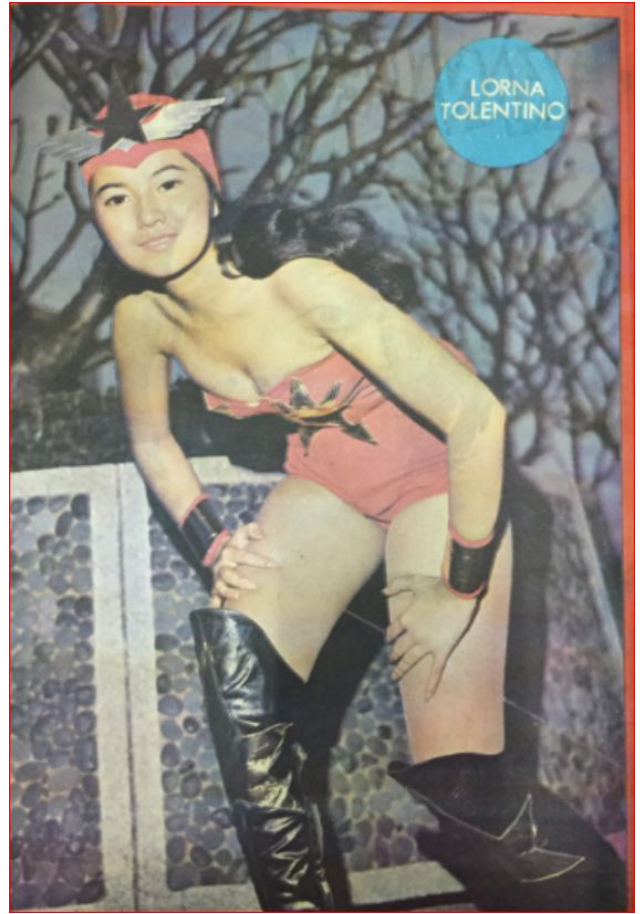

Figure 3. Lorna Tolentino as Darna in the first live-action television series (Darna Komiks, 1977, UP Diliman Library).
Navoa \& Robinson, 1980). Santos wore a red bra with gold stars and dangling chains, blue shorts, white loincloth, red and gold headdress, gold bracelets, belt, and boots.

Darna first flew to the small screen in 1977 in a short-lived television series produced by RPN9. She was played by an up-andcoming young star named Lorna Tolentino (see fig. 3) who wore a red one-piece suit emblazoned with gold stars, gold boots and bracelets, and a gold star on top of the usual wings that adorn the red headdress. The selection of Rio Locsin in Bira, Darna, Bira (Go, Darna, Go) in 1979 possibly signaled a change in how the actresses were chosen as Darna. Rio Locsin was initially known as a sexy star and on that same year, her film Disgrasyada (Disgraced, 
1979), ruled the box-office. In Bira, Darna, Bira (Martinez \& Sanchez, 1979), she wore the traditional red two-piece with gold star, yellow loincloth, gold bracelets and boots, and a choker.

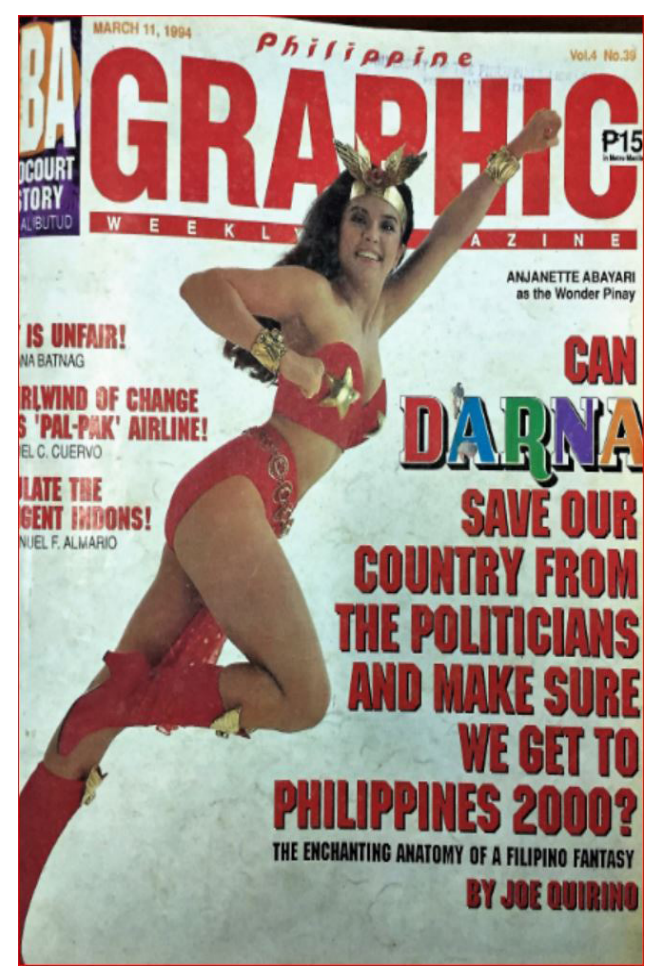

Figure 4. Anjanette Abayari as Darna (Philippine Graphic, 1994, UP Diliman Library).

In the nineties, Viva Films produced two Darna movies featuring their contract stars Nanette Medved in Darna (1991) and Anjanette Abayari in Darna: Ang Pagbabalik (Darna: The Return, 1994). Both were FilipinoAmerican citizens who tried their luck in the country and were considered sex symbols at the height of their popularity. Darna's costume became sexier and more revealing in this period. In Darna (del Rosario \& Lamangan, 1991), Medved still wore the traditional two-piece red suit, the shorts became a high cut bikini, with gold stars, red boots and loincloth, silver bracelets, and a tiara instead of a headdress. In Ang Pagbabalik (del Rosario, Gallaga \& Reyes, 1994) Abayari followed the same design, but with modifications on the tiara which looked more like two intertwined leaves than the traditional bird wings; and the belt which replaced the medallion with a star (see fig. 4).

While there has not been any Darna movies since the nineties (though Star Cinema has been developing one since 2015), GMA Network produced two television series headlined by Angel Locsin (Quizon \& Zapata, 2005) and Marian Rivera (Zapata \& Perez, 2009). In terms of the costume, Angel Locsin adhered to the original Rosa del Rosario costume, which Marian Rivera followed, but replaced the white loincloth with yellow, while the winged headdress became slimmer.

So what role did Darna's costume play in the transformation of the bodies of these actresses into a spectacle? The next section incorporates the discussion of how entertainment articles ritualized and aestheticized the bodies of these celebrities in an effort to market Darna's adaptations. 


\section{Darna as a spectacle: Ritual and aesthetics}

Kellner (2003) sees ritual as part of spectacle because it highlights the values and ideals relevant to a particular society. Ritualistic practices hold people together. Sporting events like the Olympics, or award shows such as the Oscars, or the Ms. Universe pageant are rituals not only because they emphasize the values of camaraderie, teamwork, excellence, beauty, and intelligence, but also becomes a focal point of people coming together to witness an event.

One of the rituals involved in the spectacularization of Darna is the emphasis placed by press releases on her importance in Filipino culture and the role that she plays as a popular culture icon. In Figure 5 for example, she is described as the embodiment of Filipinos' oppression, marginalization, and continuing fight for justice and equality.

Figure 5. An article in Liwayway Magazine (1965, taken from National Library Microfilm).

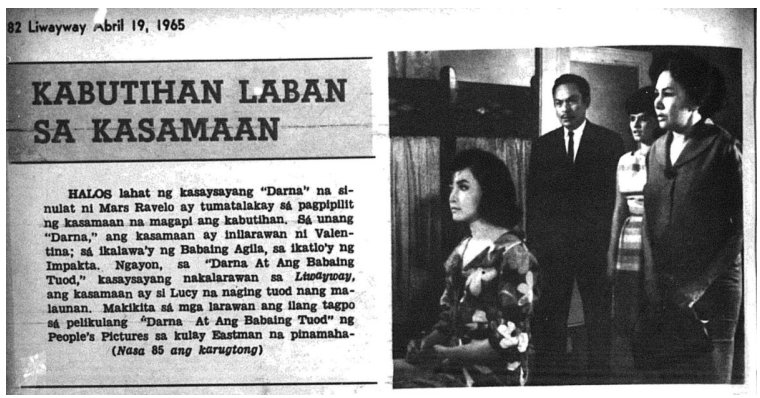

The same theme of Darna as a champion for the Filipinos can still be found twenty-nine years later in Joe Quirino's (1994) article that appeared in Philippine Graphic, describing her as a "heroine for all seasons but is principally a champion of the masses" (p. 25).

Another practice is by celebrating Darna's "vaunted" history in publicity materials. This is done by associating Darna with the legacy of Mars Ravelo and with the previous actresses who donned the red costume. Several entertainment articles (Jorge, 2005; Quirino, 1994; Ramos, 1977; "Enter the new Darna," 1972) and the 2005 and 2009 Darna primers produced by GMA-7, constantly referred to Darna as a creation of Mars Ravelo. The strategy of always emphasizing the creator of the character is a prominent feature in comic books, especially in superhero stories. This is similar to the notion of auteurs - individuals who have put a stamp on a cultural product so much so that it comes with it its own notions of prestige and legacy. In the same vein, being chosen as Darna comes with a certain badge of honor as they are now part of an "exclusive club" of actresses. The names of Rosa del Rosario, Liza Moreno, Gina Pareno, Vilma Santos also comes up in publicity materials with accompanying stories on how portraying Darna is a "dream 
role" for any actress and that it not only enhances their popularity, but also cements their place in popular culture history (Jorge, 2005; Quirino, 1994; Vibas, 2005; "Enter the new Darna", 1972; "Ipinanganak ng Darna”, 1973). Rome Jorge (2005) in an article for Manila Times sums up the value of what it means to be cast as Darna:

To play her part, or even those of her friends and foes, is a coveted prize that immortalizes actors and defines careers. Those who walk in their shoes are among giants and legends (para. 21).

Spectacle is also obsessed with aesthetics which is loosely defined as media's tendency to turn any event into a dramatic narrative in order to capitulate on emotions which can lead to ratings or profit (Kellner, 2003, pp. vii-viii). In this paper, aestheticization is seen in the way entertainment articles focus on stories about how the actresses prepared for the role, but mostly centering on the physicality of the role and appearance. In this case, as stars are products of a capitalist system, their bodies have a corresponding labor and value (Dyer, 1987). The labor comes in the form of how celebrities comply to idealized notions of what a superhero body should be. Once this is achieved, they are put on display for consumption by fans.

How are Darna actresses aestheticized as spectacles by entertainment writers?

One is by detailing their physical regimen, diet, and training. Another is by reducing their bodies to numbers and figures deemed sexually acceptable and pleasing to the public.

Entertainment articles about Darna actresses relied heavily on stories about diet, exercise, and other physical training. As for example, Montes pointed out the demands made on her body when she was chosen to depict Darna. She was subjected to the rigors of physicality more than the (acting) talent which made her worry about her safety while doing stunts ("Darna stars face test in new Ravelo thriller", 1965).

Although the role of Darna does not require so much of talent but more strength, stamina and speed. I also found it very trying and difficult. I did not know anything about boxing, judo or karate and I had to study these for several weeks. (para. 6)

In another article, Angel Locsin explains how her busy schedule did not allow her to "go to the gym at all to become more shapely and toned for my tough superheroine role" (Vibas, 2005, para. 18). Angel Locsin also had to refute news about a 'breast augmentation' just to look sexy (Vibas, 2005, 
para. 26) and that she needed to go on a diet in order to look good wearing Darna's costume.

Pa'no ko kung magda-diet ako eh di dinadala nyo na lang ako na naka-dextrose habang nakikipag-fight scene di ba? Pangalawa, di ka naman pwede magtipid sa pagkain. Kailangan mo ng rice kasi manghihina ka eh. Di ka makakapag-memorya ng mga linya mo tapos malamya ka kumilos, na di naman pwede kasi dapat malakas ka eh (personal communication, July 2, 2006).

[What will happen to me if I go on a diet? You might have to carry me with a dextrose while doing fight scenes. Second, you really have to eat well. You need to eat rice, otherwise you will feel weak. You cannot memorize your lines and then you will look weak which cannot happen because you have to look strong.]

More importantly however, publicity materials were preoccupied with detailing how Darna actresses shape their bodies to fit into Darna's revealing costume. In the same interview, Angel Locsin also admitted that the costume puts pressure on her body because she needs to appear flawless, sexy, and with abs (abdominal muscles) for the role. Florencio Viray (2009) also blogged about how Vilma Santos was initially so conscious of her body that she wore a stocking underneath her costume during the press conference for Lipad, Darna, Lipad. It was only when she was assured by the Sine Pilipino producers that she's also sexy that she decided to remove the body stockings. This is not surprising since some producers are very vocal in making sure that Darna's costume looks good on whoever is wearing it. William Leary (as cited in Landicho \& Mirandilla, 1999) said as much in the transcript of this interview:

We really had to think about the costume. Because if the costume doesn't fit Darna, then how can she move or fly? And lahat sila kailangan ang size ng costume one size smaller para mas mukhang malaki yung boobs (And they all need the costume to be one size smaller so that the boobs will look bigger). (p. 79)

Redgie Magno (personal communication, May 26, 2006) also echoed this: "Oo kailangan physically fit sya kasi ang pangit naman ng Darna na nakita mong naka-exposed yung body nya tapos ang pangit ng hitsura" 
(Yes, she should be physically fit because it would not be nice to see Darna's body exposed and it looks ugly).

It seems that the requirement for playing Darna had more to do with how good they look while wearing the red two-piece. However, entertainment articles do not just celebrate how these women get into shape, but also detail their struggle to push their bodies to the limit. Liza Valdez (1969), in an article in Sixteen Mag, wrote about Gina Pareño's difficulty in losing weight when she was chosen to play Darna. The article went on to mention that the pressure became too much for Pareño because she was also compared to Jane Fonda's Barbarella (1968) which was shown the year prior. After her exercise and diet failed to eliminate all the excess fats in her body, she went to the doctor and requested for dieting pills which she also took with other pills to fast-track her weight loss which resulted in her hospitalization.

Another way promotional materials aestheticize Darna is through the practice of quantifying the female body by giving it value. Entertainment writers call attention to the vital statistics (focusing on the size of their breast, waist, and hips) of these women in press releases and write-ups. Gina Alonzo, who played Impakta (Monster), was introduced in an article in Liwayway Magazine like this:

Batam-bata pa si Gina: 17 taong gulang lamang. Maganda. May mga matang mapupungay; maamong mukha at larawan ng kawalang malay; may magandang hubog ng pangangatwan, 34-23-35. May kahali-halinang tindig: limang talampakan at limang pulgada ang taas, isang sukat na naaangkop sa kanyang personalidad at taglay na gulang (Morota, 1963, p. 64).

[Gina is still young: 17 years old. Beautiful. She has languid eyes, a gentle face that is the embodiment of innocence; she has a shapely body, 34-23-35. She has an attractive stature: five feet and 5 inches tall, a height that befits her personality and age.]

The same strategy is seen in the description of Lorna Tolentino in an article written in Darna Komiks:

Nang kami'y makababa at habang muling minamalas ng mga taga-Nichols and 5'4" height, 34-23-34 whistle bait figure ni Lorna, nangangalog naman ang aming tuhod (Ramos, 1977, p.3).

[When we landed and while people from Nichols were 
admiring Lorna's height and whistle bait figure, 34-23-34, our legs were shaking.]

In the same interview, Quirino (1994) described Anjanette Abayari as: “weighing 115 lbs., 5'5' in height and measuring 35-23-35". He also mentioned that Abayari joined a pageant scoring "high on intelligence, beauty of the face, and beauty of figure" (p. 25). Nanette Medved was described in another Liwayway Magazine article in this manner: "sa taas niyang taglay, at ganda ng pangangatawan, p'wede syang gawing model" (With her height and beautiful figure, she can be a model) ("Nanette Medved, Bagong Dyesebel?", 1991). Interestingly, this strategy is noticeably absent when writing about local male stars.

The intention in foregrounding the body as a spectacle is rooted on how the superhero genre has typically presented the body either through hypersexualization for women and masculinization for men. Darna is an interesting example in exposing the contradictions inherent in the presentation of the superhero body because she appeals to both children and adults, men and women. She straddles the line between being idealized and sexualized. Within the narrative, Darna is an idealized figure. Narda, her mortal alter-ego is portrayed as down to earth, simple, gentle, kind-hearted, and sacrificing so much so that when she transforms to Darna and her body is exposed, she is not sexualized, but rather equated with perfection and confidence.

It is a different story though when we talk about adapting Darna into other media. Here, producers, including writers and directors, the actresses themselves, and the entertainment press add another layer to Darna. Instead of using spectacle to highlight the extraordinary feats of power and greatness of the superhero, spectacle is transferred and transformed into the bodies of actresses who are given the opportunity to perform Darna onscreen. In becoming Darna, their bodies had to be disciplined and controlled so as to provide tangible proof that they are worthy to wear the iconic red costume. Neferti Tadiar (2004) said it best when she notes that it is through the "spectacle of the body that tragic tales are told" (p. 123).

Here, it is important to point out the pivotal role played by the public relations industry, specifically by the entertainment press in the creation of spectacle. Graeme Turner (2004) sees a transactional pattern that is beneficial to both television and film companies and the entertainment press. In the time before celebrities use social media to directly give access to their lives, it is the press who provides the access to the audiences to get to know these celebrities. They are also vehicles for promoting, hyping, and putting these stars in the public consciousness. In return, the movie and 
television companies provide the entertainment press the materials that is their raison d'etre. Both are helping each other to achieve their professional goals of getting their captured market. Turner notes that there is danger in this kind of arrangement because the process is deliberately mystified or made invisible to maintain the status quo (p. 45).

This is where transforming Darna into a spectacle in these entertainment articles become a concern. As an integral part of the culture industry, entertainment press are the instrument for churning out spectacles that can entertain, distract, or amass support for or destroy certain celebrities. It is said that one of the reasons that Bira, Darna, Bira did not fare so well at the box-office was because of the negative publicity surrounding the production of the film which includes the near firing of the director, the producer's conflict with the management of Rio Locsin, among others ("Mga Problema sa Pagsasapelikula", n.d.).

The entertainment press' focus on the bodies of female celebrities can be seen as a form of control and distraction. Control is seen in terms of how these articles seemed to dictate an idealized body for both the superhero character and the actresses, even though Darna's stories in the komiks have never been focused on her looks. Further, control is also manifested in immortalizing a narrative that centers on legacies and histories. This strategy serves the actresses and the film and television producers. The actresses are elevated to a certain status and committed to popular culture memory as they get their names repeated over and over again in succeeding promotional materials. The film and television producers also benefit as they associate their products to Darna's longevity, value, and importance in society for promotions and profit.

Entertainment articles also present these actresses as spectacles to distract us from talking about the subversive potential of superheroes. Darna's symbolical power is dissolved when we shift the conversation away from her relevance into how celebrities undergo a regimen to sculpt their bodies into a desired state. Instead of talking about how Darna embodies the struggle of Filipinos as they demand for justice and a better life, we are entertained by the preparation of these actresses-how they exercised and went on a diet, their vital statistics, or whether they had surgery to improve a certain body part. Spectacularizing female bodies in the publicity and promotional materials are all the more insidious and dangerous because it prevents us from harnessing the full extent of Darna's representational powers in popular culture, something that do not serve the needs of the capital.

Unfortunately, this is now something that is happening to Darna. As seen in Figure 6, the reactions and opinions of fans have mostly been on 
the physical body as a consideration for selecting and being Darna rather than on how actresses should embody who she is as a superhero. Suddenly, Darna is not just a Filipino superheroine who wants to save the world. Now she also needs to be beautiful, sexy, athletic, and with a body fit to wear the iconic red costume.

Figure 6. Fan comments from different komiks-magazines. Taken from Herbert Chavez Darna Collection (UP Diliman Library).

"Physically, I think it's Anjanette. But you know, it's not just the personality eh. Ang Darna is somebody who also has novelty, kaya I can say na that is Vilma Santos. Kasi although she's not that sexy, she was able to portray the role very well and the movie indeed saved her dying career at that time. II's really an all-time box office hit, kaya Vilma pa rin."
-Depende rin kasi 'yan kung saan mo ibe-base. Pero para sa akin lalaga, it's Vilma Santos, kasi 'yung star persona ni Vilma is more than enough para maging convincing siya as Darna. Kasi nagpo-project 'yon ng pagiging heroine eh. Pero kung ang basis mo naman ay 'yung appearance, I'Il choose Anjanette kasi nu'ng nakita ko siyang naka. costume, talagang appearance. wise, pertect siya. But when it comes to persona and image, it's Vilima, still."
“Ang pinakamaraming series na nagawa riyan, si Vilma, so far. Hindi pa natin nakikita si Anjanette kaya hindi pa natin mada-judge. Si Nanette Medved, parang napakapayat na Darna. Si Rosa del Rosario, she was very convincing at that time, although noong nakita ko 'yung video, parang hindi na ganoon ngayon. But you see, Darna is supposed to be a Filipino wonder woman, ewan ko kung paano idedeliver ni Anjanette 'yong mga lines niya. Siguro, kaya lang siya naging Darna is because of her Tamaraw commercial. Pero wala, I don't think she's supposed to be Darna. Kasi kano ang dating niya eh. 'Yong Darna, wholesome, eh kung merong mga betamax issue, hindi na wholesome 'yon.
"For me, it's Vilma, kasi nake apat siyang Darna eh. Ibig sabihin noon, gusto siya ng mga tao, gusto siya ng producer kasi ginawan siya ng apat na sequel. Unlike 'yong iba na tig-iisa lang. Which means na kumita talaga ang mga Darna movies ni Vilma.

Puwede rin si Anjanette, kas sexy siya eh. Sexy and boobsy kaye bagay sa kanya 'yong costume ng Darna. But performance-wise, it's really Vilma kasi she had tou sequels of the movie."

\section{Conclusion}

This paper is an exploration of an often-overlooked topic in Darna and popular culture studies - the spectacle of celebrity bodies in the superhero genre. Popular culture texts like Darna and the accompanying articles written by the entertainment press are relevant sources of analysis because as Kellner (2003) notes, they capture the attention and imagination of vast audiences (p. 17). These cultural texts are popular precisely because they are continuously spectacularized through rituals and aesthetics.

As a commodity, the star/celebrity, just like any other product, is put on display to ensure his/her marketability and continued relevance to their target market. In Darna, this is done by putting the celebrity body front and center in the available promotional materials which provide details on how these actresses are being physically trained for the role, how they are required to go on a diet, how they are asked to endure pain to make sure 
their bodies look good, not in the service of playing and being true to Darna's character, but rather as a means to comply with the demands of the capital.

Things do not seem to be changing anytime soon as a quick look at entertainment articles about Star Cinema's plan to produce Darna continues to highlight only the physical requirement: a Filipina look, a beautiful face, and a sexy body (Severo, 2019). The assumption that these are what an actress needs to become Darna or any superhero for that matter, needs to be debunked because it results in a discourse that obscures Darna's importance in our culture.

There are ways this can be addressed. One is to reimagine Darna's costume, taking its cues from other contemporary superheroines like Captain Marvel (Feige, Boden \& Fleck, 2019) who is reconfigured as a response to changing ideas about how female superheroes should look like. Reimagining Darna's costume can be done without losing the essence of what it symbolizes.

Another is for the entertainment industry to revisit how Mars Ravelo imagined and constructed Darna as a character. Revisiting do not literally mean translating all of Ravelo's original conceptualizations and storylines in the adapted works, but rather acquiring a deeper understanding of who Darna is and why she was written in a certain way. Revisiting and rereading Darna would reveal that it is Narda, whether as a child or a grown-up, who is the symbol of the common Filipino. The one who struggles on a daily basis but continues to work hard to achieve a fully realized self. That idealized and realized self is Darna. This is why earlier Ravelo stories presented Narda and Darna as two different people because they are representations of who the Filipino is and could be, and it does not matter whether one has a beautiful face or a sexy body. 


\section{References}

Angel Locsin shouts 'Darna'. (2005, March 17). 24 Oras. GMA Network.

Arriola, J. (2013). Pelikulang komiks: Towards a theory of Filipino film adaptation (Unpublished doctoral dissertation). University of the Philippines College of Mass Communication: Diliman, Quezon City.

Benedicto, K. (Producer). (1977). Darna [Television Series]. Philippines: RPN-9.

Boney, A. (2013). Superheroes and the modern(ist) age. In R. S. Rosenberg \& P. Coogan (Eds.), What is a superhero? (pp. 43-48). New York: Oxford University Press.

Brillon, C. A. B. (2007a). Darna and intellectual property rights. Plaridel: A Journal of Philippine Communication, Media and Society, 4(1), 97-114.

Brillon, C. A. B. (2007b). Manufacturing a GMA telefantasya: A political economy case study of Darna TV Series (Unpublished graduate thesis). University of the Philippines College of Mass Communication: Diliman, Quezon City.

Campos, P. (2009). The fantasy-adventure films as contemporary epics, 2000-2007. Plaridel: A Journal of Philippine Communication, Media and Society, 6(1), pp. 1-36.

Darna stars face test in new Ravelo thriller. (1965, March 30). The Daily Mirror. From the Herbert Chavez Darna Collection.

Debord, G. (1995). The society of the spectacle (1st ed.) (D.N. Smith, Trans.). New York: Zone Books.

Dyer, R. (1987). Heavenly bodies: Film, stars and society. England: MacMillan Education.

Enter the new Darna. (1972, December 07). Darna Komiks, 3(91). UP Diliman Library

Escobar, A. (2010). Lipad, Darna, lipad! A comparative textual analysis of the image of Darna as a Filipina in television (Unpublished undergraduate thesis). University of the Philippines College of Mass Communication: Diliman, Quezon City.

Feige, K. (Producer), \& Boden, A. \& Fleck, R. (Directors). (2019). Captain Marvel [Film]. USA: Marvel Studios.

Gerona, J., Goze, R., Lumidao, S. J., \& Yu, S. (2009). Darna for sale: A political economy case study on the implications of copyright in the adaptation of Mars Ravelo's Darna (Unpublished undergraduate thesis). Far Eastern University, Manila.

Gibson, M., Huxley, D., Ormrod, J. (2015). Superheroes and identities: An introduction. In M. Gibson, D. Huxley, \& J. Ormrod (Eds.), Superheroes and identities. [Kindle version]. Retrieved from Amazon.com.

Gray, R.J. II. (2011). Vivacious vixens and scintillating super hotties. In R. J. Gray \& B. Kaklamanidou (Eds.), The $21^{\text {st }}$ century superhero: Essays on gender, genre, and globalization in film. [Kindle version]. Retrieved from Amazon.com.

Ipinanganak ng Darna ang isang bagong superstar. (1973 April 19). Darna Komiks, 5(20). UP Diliman Library.

Jacobus, M., Keller, E.F., \& Shuttleworth, S. (1990). Body/Politics: Women and the discourses of science. New York, London: Routledge.

Jorge, R. (2005 November 27). Darna and the giants. Manila Times Online. Retrieved from http://www. manilatimes.net/national/2005/nov/27/yehey/weekend/20051127week1.html.

Kellner, D. (2003). Media spectacle. London: Routledge.

Landicho, C. G. S. \& Mirandilla, K. A. (1999). Metamorphosis of Filipino values in fantasy films: A textual interpretation of Darna in its four selected movie versions (Unpublished undergraduate thesis). University of the Philippines College of Mass Communication: Diliman, Quezon City. 
Lanot, M. PL. (2001). Bomba forever? The images of women in bomba films. In N. Tiongson, (Ed.), Pelikula: A Journal of Philippine Cinema 3(1), 16-18.

Laxa, E. (Producer), \& Garces, A. (Director). (1975). Darna vs. the planet women [Film]. Philippines: Tagalog llang-llang Productions.

Laxa, E. (Producer), \& Borlaza, E. H. \& Diaz, L. (Directors). (1973). Darna and the giants [Film]. Philippines: Tagalog Ilang-Ilang Productions.

Laxa, E. (Producer), \& Catindig, N. B. (Director). (1963). Isputnik vs. Darna [Film]. Philippines: Tagalog Ilangllang Productions.

Lent, J. A. (2009). The first one-hundred years of Philippine komiks and cartoons. Tagaytay City: Yonzon Associates.

Lucero, R.C. (2001). Fish, goddess, superwoman and forest nymph: Women in fantasy films. In N. Tiongson, (Ed.), Pelikula: A Journal of Philippine Cinema 3(1), 10-12.

Madrid, M. (2009). The supergirls: Fashion, feminism, fantasy and the history of comic book heroines. [Kindle version]. Retrieved from Amazon.com.

Martinez, A. (Producer), \& Sanchez, T. (Director). (1979). Bira, Darna, bira (Go, Darna, go) [Film]. Philippines: MBM Productions.

McDaniel. A. (2014). Negotiating life spaces: How marriage marginalized Storm. In M. B. Carter, N. Jones, \& B. Batchelor (Eds.), Heroines of comic books and literature: Portrayals in popular culture, (pp. 119131). Maryland, UK: Rowman and Littlefield.

McDonald, P. (2000). The star system: Hollywood's production of popular identities. London: Wallflower Press.

Meyers, E. (2014). Gossip blogs and "baby bumps": The new visual spectacle of female celebrity in gossip media. In K. Ross (Ed.), The handbook of gender, sex, and media, (pp. 53-70). West Sussex, UK: John Wiley \& Sons, Inc.

Mga problema sa pagsasapelikula ng "Bira, Darna, Bira”. (n.d.). Taken from the Herbert Chavez Darna Collection, UP Diliman Library.

Morota, R. L. (1963, June 6). Gina Alonzo: Bituin sa unang pelikula (Gina Alonzo: A star in her first movie). Liwayway Magazine, 64-65. From Video 48, with permission.

Muhlach, A. (Producer), \& Navoa, J. E. \& Robinson, C. (Directors). (1980). Darna at Ding (Darna and Ding) [Film]. Philippines: D'Wonder Films.

Nanette Medved, bagong Dyesebel? (Nanette Medved, The new Dyesebel?). (1991, July 29) Liwayway Magazine, 10, 38.

Perez, J. (Producer), \& Navarro, M. (Director). (1969). Si Darna at ang planetman (Darna and the planetman). Philippines: Vera-Perez Pictures.

Poe, F. (Producer), \& Tolosa, C. V. (Director). (1952). Darna at ang babaeng lawin (Darna and the hawk woman) [Film]. Philippines: Royal Productions.

Poe, F. Sr. (Director \& Producer). (1951). Darna [Film]. Philippines: Royal Productions

Pyle, C.L. (1994). The superhero meets the culture critic. Postmodern Culture 5(1), doi:10.1353/ pmc.1994.0057.

Quirino, J. (1994 March 11). Darna through the years: The anatomy of a Filipino comics and film fantasy. Philippine Graphic, pp. 24-26. 
Quizon, E. \& Zapata, D. (Directors). (2005). Darna [Television series]. Philippines: GMA Network.

Quijano, D. (Producer), \& Borlaza, E. H., Perez, E. (Directors) \& Gosiengfiao, J. (Director and Producer). (1973). Lipad, Darna, lipad (Fly, Darna, fly) [Film]. Philippines: Sine Pilipino Productions.

Ramos, C. (1977). 800,000 feet sa himpapawid with Lorna Tolentino (800,000 feet in the air with Lorna Tolentino). Darna Komiks, 1-3, Circulation and User Services, University of the Philippines Diliman Main Library, Quezon City.

Reyes, S. S. (2009). From Darna to Zsazsa Zaturnnah: Desire and fantasy: Essays on literature and popular culture. Pasig City: Anvil Publishing Incorporated.

Reyes, S. S. (2001). Sa puwang ng machismo: Women in FPJ movies (In between the gaps of machismo: Women in FPJ movies). In N. Tiongson, (Ed.), Pelikula: A Journal of Philippine Cinema 3(1), 4-7.

del Rosario, V. (Producer), \& Gallaga, P. \& Reyes, L. (Directors). (1994). Darna: Ang pagbabalik (Darna: The return) [Film]. Philippines: Viva Films.

del Rosario, V. (Producer), \& Lamangan, J. (Director). (1991). Darna [Film]. Philippines: Viva Films.

Salkowitz, R. (2018 December 26). How superhero movies dominated the box-office in 2018. Forbes. Retrieved from https://www.forbes.com/sites/robsalkowitz/2018/12/26/how-superhero-moviesdominated-the-box-office-in-2018/\#14bf28616f0c

Santiago, A. (2001). The new Filipino woman in five landmark melodrama films. In N. Tiongson, (Ed.), Pelikula: A Journal of Philippine Cinema 3(1), 7-9.

Santiago, C. H. (Director \& Producer). (1965). Darna at ang babaeng tuod (Darna and the wooden monster). Philippines: Cirio H. Santiago Productions, People's Pictures.

Santiago, D. (Director). (1963). Darna at ang impakta (Darna and the monster) [Film]. Philippines: People's Pictures.

Severo, J.M. (2019 May 3). Stars nominated to be the next Darna. Philippine Star Online. Retrieved from https://www.philstar.com/entertainment/2019/05/03/1914689/list-stars-nominated-be-nextdarna.

Tadiar, N. X. M. (2004). Fantasy-production: Sexual economies and other Philippine consequences for the new world order. Quezon City: Ateneo de Manila University Press.

Tasker, Y. (1993). Spectacular bodies: Gender, genre and the action cinema. New York: Routledge.

Turner, G. (2004). Understanding celebrity: London: Sage Publications.

Valdez, L. (1969). RP's Answer to Barbarella: Gina Pareño. Sixteen Magazine, 57-58. Retrieved from https:// pelikulaatbp.blogspot.com/search?q=darna.

Vibas, D. (2005 March 30). Now, it's Darna!. Manila Times Online. Retrieved from http://www.manilatimes. net/national/2005/mar/30/yehey/life/20050330lif1.html .

Viray, F. (2009 November 30). Film review: Darna and the giants. Retrieved from https://starforallseasons. com/2012/04/28/darna-and-the-giants-tagalog-ilang-ilang-productions-1974/.

Zapata, D. \& Perez, D.M. (Directors). (2009). Darna [Television series]. Philippines: GMA Network. 


\section{Endnotes}

${ }^{1}$ This is an excerpt from the dissertation entitled "Darna and the intermediality of the Filipino superhero genre". This is also a revised version of a paper presented in the International Research Forum on the Philippines (IRFP) on Becoming Filipino held in La Trobe University from 26-27 November 2018.

${ }^{2}$ The following were used for analysis: Pilipino Komiks, Kampeon Komiks, Darna Komiks, Liwayway Magazine, Philippine Graphic, Manila Times, FHM Magazine, Esquire Magazine, and GMA-7's two partprimer on Darna 2005 aired last March 31-April 1, 2005 and Darna 2009 aired last August 2009. 


\section{Grant Support Details}

Author Contributions: All research activities and writing were done by C. A. A. Brillon. The author has read and agreed to the published version of the manuscript.

Funding: This paper was part of a PhD in Philippine Studies dissertation entitled Darna and the Intermediality of the Superhero Genre which was partially funded by the Commission on Higher Education Dissertation Grant in 2017.

Acknowledgements: The author would like to thank the reviewers for their helpful insights on the article and the Plaridel editorial and publication staff for all their assistance and support. The author also wishes to thank the National Library and the UP Diliman Library for the use of their archives including Darna fans such as Herbert Chavez, Mike Virtucio, and Eric Cueto, Simon Santos (Video 48), and Florencio Viray (Star for All Seasons website) for the wealth of Darna materials that they have made available to fans and researchers alike.

Conflict of Interest: The author declare no conflict of interest. The funders had no role in the design of the study; in the collection, analysis, or interpretation of data; in the writing of the manuscript, or in the decision to publish the results.

\section{About the Author}

CHERISH AILEEN A. BRILLON teaches at the University of the Philippines Diliman Broadcast Communication Department. She obtained her Ph.D. in Philippine Studies at the UPTri-College Program, Asian Center. Her main interests include political economy of communication, gender, and popular culture. (corresponding author: iris.brillon@gmail.com) 